\title{
SEALING ABILITY OF CASTOR OIL POLYMER AS A ROOT- END FILLING MATERIAL
}

\author{
Giovana Ribeiro de MARTINS ${ }^{1}$, Claudio Antonio Talge CARVALHO ${ }^{2}$, Marcia Carneiro VALERA ${ }^{3}$, Luciane Dias de OLIVEIRA ${ }^{4}$, \\ Leonardo BUSO ${ }^{5}$, Alessandra Sverberi CARVALHO ${ }^{6}$
}

\author{
1- MsC in Endodontics, Dental School of São José dos Campos, São Paulo State University, São José dos Campos, SP, Brazil. \\ 2- MsC, PhD, Professor, Department of Restorative Dentistry and Endodontics, Dental School of São José dos Campos, São Paulo State University, \\ São José dos Campos, SP, Brazil. \\ 3- MsC, PhD, Adjunto Professor, Department of Restorative Dentistry and Endodontics, Dental School of São José dos Campos, São Paulo State \\ University, São José dos Campos, SP, Brazil. \\ 4- MsC, PhD, Department of Biosciences and Oral Diagnosis, Dental School of São José dos Campos, São Paulo State University, São José dos \\ Campos, SP, Brazil. \\ 5- MsC, PhD, Department of Dental Materials and Prosthodontics, Dental School of São José dos Campos, São Paulo State University, São José dos \\ Campos, SP, Brazil. \\ 6- MsC, PhD Student, Department of Restorative Dentistry and Endodontics, Dental School of São José dos Campos, São Paulo State University, São \\ José dos Campos, SP, Brazil.
}

Corresponding address: Alessandra Sverberi Carvalho - Rua Paraibuna 55, apto 1312 - Jd São Dimas - São José dos Campos- SP -12245-020 - email:alessandra.sverberi@itelefonica.com.br

Received: June 24, 2008 - Modification: October 09, 2008 - Accepted: November 09, 2008

\begin{abstract}
$O$

bjective: The purpose of this study was to evaluate the sealing ability of castor oil polymer (COP), mineral trioxide aggregate (MTA) and glass ionomer cement (GIC) as root-end filling materials. Forty-five single-rooted human teeth were cleaned and prepared using a step-back technique. The apical third of each root was resected perpendicularly to the long axis direction. All teeth were obturated with gutta-percha and an endodontic sealer. After, a root-end cavity with $1.25-\mathrm{mm}$ depth was prepared using a diamond bur. The specimens were randomly divided into three experimental groups $(\mathrm{n}=15)$, according to the root-end filling material used: G1) COP; G2) MTA; G3) GIC. The external surfaces of the specimens were covered with epoxy adhesive, except the root-end filling. The teeth were immersed in rhodamine B dye for 24 hours. Then, the roots were sectioned longitudinally and the linear dye penetration at the dentin/material interface was determined using a stereomicroscope. ANOVA and Tukey's tests were used to compare the three groups. The G1 group (COP) presented smaller dye penetration, statistically different than the G2 (MTA) and G3 (GIC) groups $(\mathrm{p}<0.05)$. No statistically significant difference in microleakage was observed between $\mathrm{G} 2$ and G3 groups ( $>0.05)$. The results of this study indicate that the COP presented efficient sealing ability when used as a root-end filling material showing results significantly better than MTA and GIC.
\end{abstract}

Key Words: Castor oil polymer. Marginal sealing. Microleakage. Root-end filling material.

\section{INTRODUCTION}

The predictable success of endodontic treatment depends on cleaning, mechanical instrumentation of root canal system, elimination of microorganisms and their by products and organic debris, and complete root canal filling. However, various factors have been reported which contribute to the failure of root canal treatment, mainly the presence of persistent intraradicular infection ${ }^{1}$. Endodontic surgery may be indicated in a number of cases or situations including: a strong possibility of failure from nonsurgical treatment; failure of nonsurgical treatment in which retreatment is either not possible or unlikely to result in a better outcome; necessity of biopsy at or close to the tooth apex ${ }^{4}$; excessive calcification of the root canal system; teeth restored with post and core crowns, iatrogenic shoulders or ledges, iatrogenic perforation of the canal ${ }^{6}$.

In these cases, when periapical surgery is indicated, it is frequently necessary to place a root-end filling ${ }^{6}$. The main objective of a root-end filling material is to provide an apical seal that prevents the movements of bacteria and the diffusion of bacterial products from root canal system into the periapical tissues ${ }^{5}$. An ideal root-end filling material should be biocompatible, nontoxic, easy to manipulate, radiopaque, dimensionally stable, unaffected by humidity, non-absorbable, cost-effectiveness and adhesive to dentin ${ }^{5}$. Several materials have been proposed as root-end fillings, including amalgam, zinc-oxide-eugenol cements, glass ionomer cements (GICs), gutta-percha, intermediate restorative material (IRM), super ethoxybenzoic acid (Super 
EBA), resin composite and mineral trioxide aggregate $(\mathrm{MTA})^{4}$. However, none of them has yet presented the characteristics of an ideal material ${ }^{5}$.

The use of MTA in root-end cavities has been extensively demonstrated. Torabinejad, et al. ${ }^{14}$ showed that MTA has better sealing ability than amalgam and super EBA as rootend filling material. Also, Torabinejad, et al. ${ }^{12}$ verified that the use of MTA as root-end filling material in teeth of monkey was associated with significantly less inflammation, cementum formation placed over MTA, and regeneration of the periradicular tissues to almost normal preexperimental status. Mangin, et al. ${ }^{7}$ showed the ability of hydroxyapatite cement, MTA and Super-EBA to prevent the leakage of bacteria from root canals, when used as root-end filling materials, and no significant difference was found between the leakage rates of the three materials tested. Tang, et al. ${ }^{11}$ verified that MTA promoted less endotoxin penetration than IRM and amalgam at 1, 2, 6 and $12 \mathrm{wk}$ $(\mathrm{p}<0.05)$, and less leakage than Super-EBA at 2 and $12 \mathrm{wk}$ $(\mathrm{p}<0.05)$. Since MTA has an excellent sealing ability and promotes regeneration of periradicular tissues, it seems to be more suitable as a root-end filling material compared to the commonly used filling materials such as amalgam, IRM, CIV and Super-EBA ${ }^{11,13}$.

A relatively new material, castor oil polymer (COP), has demonstrated a good potential as root-end filling material. This material has been widely used in medicine for prostheses to replace bones because it is biocompatible, nontoxic and easy to handle. This biopolymer has high interaction capacity with human cells. The chemical composition of this material presents a chain of fatty acids whose molecular structures are also present in lipid of human body 9 . Therefore, the cells do not recognize the COP as a foreign body. Recently, a constant search has been performed to find more biocompatible and organically produced materials for using in dental procedures ${ }^{9}$. The COP is a common tropical climate plant (Riccinus communis) with excellent potential for oil production, promoting a largescale supply of polyol and fatty acid prepolymers 9 . Due to these positive characteristics, it is important to evaluate its potential as a root-end filling material.

The purpose of this study was to evaluate the sealing ability of COP, MTA and GIC as root-end filling materials.

\section{MATERIAL AND METHODS}

Forty-five freshly extracted single-rooted human teeth extracted for periodontal or prosthetic reasons from patients from the Dental School of São José dos Campos, São Paulo State University, Brazil, were used. The patients have received and signed a form containing all information about the research to be performed with their extracted teeth. The teeth were selected based on their relative dimensions and similarity in morphology. Debris, calculus and soft tissue remnants on the root surfaces were cleaned using a Gracey curette and all teeth were stored in saline until use. The crowns were sectioned with carburundum discs standardizing the root lengths to approximately $16 \mathrm{~mm}$. All root canals were instrumented at $1 \mathrm{~mm}$ short of the total length $(16 \mathrm{~mm})$ up to size $50 \mathrm{~K}$-file (Maillefer, Michigan, USA). The root canals were prepared by a standardized stepback serial technique and were irrigated with $5 \mathrm{~mL}$ of $1 \%$ sodium hypochlorite $(\mathrm{NaOCl})$ solution after each instrument was changed. Then, the root canals were filled with $17 \%$ EDTA (Byofórmula Drugstore, São José dos Campos, SP, Brazil) for $3 \mathrm{~min}$, followed by a final flush with $1 \% \mathrm{NaOCl}$. All teeth were obturated with gutta-percha and AH Plus (Dentsply Ind. e Com. Ltda., Petrópolis, RJ, Brazil) using lateral condensation technique. The cervical access was sealed with Cimpat (Specialites Septodont, SP, Brazil) and the teeth were stored at $37 \pm 1^{\circ} \mathrm{C}$ and $100 \%$ humidity for 7 days.

The apical $1 \mathrm{~mm}$ of each root was resected perpendicularly to the long axis using a water-cooled diamond disk (Carbodent-Gysi S.A., Buenos Aires, Argentina). A root-end cavity with $1.25-\mathrm{mm}$ depth was prepared in all teeth using a diamond bur (1012, KG Sorensen, Brazil) under high-speed spray water cooling. The teeth were randomly divided into three experimental groups $(n=15)$, according to the root-end filling material used: Group G1: COP (Poliquil, Araraquara, SP, Brazil); Group G2: MTA (Angelus, Londrina, PR, Brazil); Group G3: GIC (SSWhite, RJ, Brazil).

Root-end filling materials were prepared according to the manufacture's instructions and placed into the root-end cavities. The castor oil's bottles and manipulation are showed in figures 2 and 3. The external surfaces of the specimens were covered with two layers of epoxy adhesive (Araldite, Brascola, SP, Brazil), except the root-end filling. The teeth were immersed in rhodamine B dye (vacuum pump for 30 $\min$ at $20 \mathrm{mmHg}$ ) and maintained at $37 \pm 1^{\circ} \mathrm{C}$ and $100 \%$ humidity for $24 \mathrm{~h}$.

After the exposure time to dye, the roots of all groups

TABLE 1- Microleakage values ( $\mathrm{mm}$ ) and standard deviation obtained in the experimental groups

\begin{tabular}{lcc} 
Groups & Microleakage $(\mathbf{m m}) \pm$ standard deviation & Homogeneous groups* \\
\hline G1 (polymeric of castor oil) & $0.69 \pm 0.35$ & $\mathrm{~A}$ \\
G2 (MTA) & $1.21 \pm 0.09$ & $\mathrm{~B}$ \\
G3 (GIC) & $1.25 \pm 0.00$ & $\mathrm{~B}$ \\
\hline
\end{tabular}

* Different letters indicate statistically significant difference 


\section{MEANS OF GROUPS}

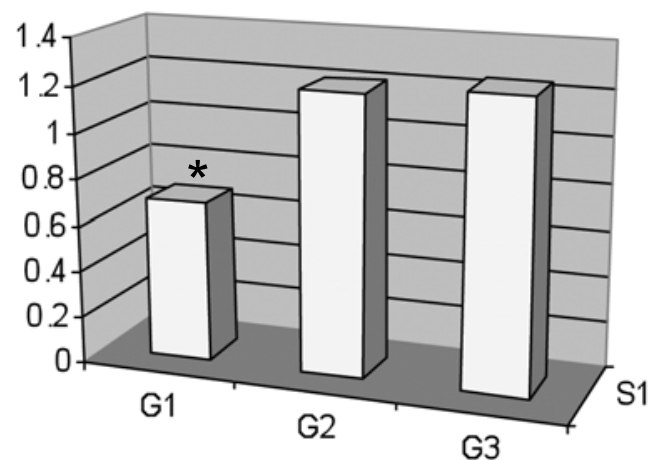

INFILTRATION (mm)

FIGURE 1- Graphic illustration of the microleakage means $(\mathrm{mm})$ in each group. * statistically significant difference as compared with the other groups

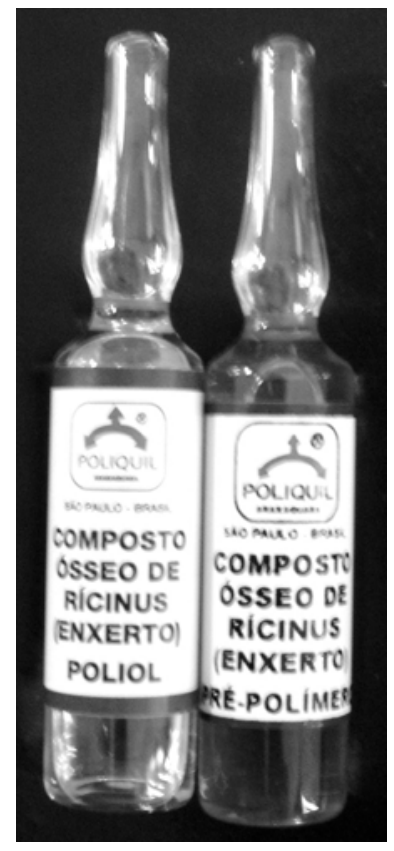

FIGURE 2- Castor oil polymer bottles

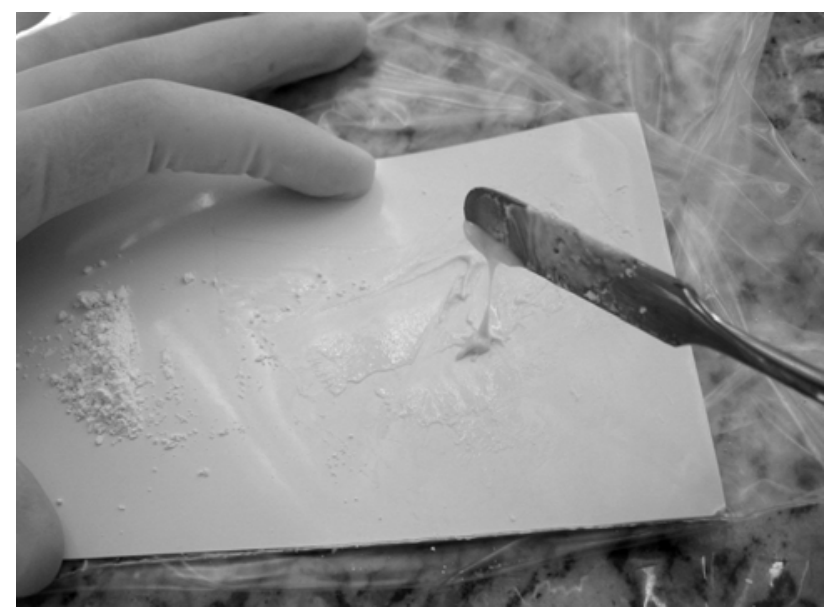

FIGURE 3- Manipulation of the castor oil polymer were sectioned longitudinally on the buccolingual plane and split up into two sections. The amount of dye penetration was examined using an optical stereomicroscope (Carl Zeiss, Germany). The linear dye penetration was measured from the resected root-end by a graduate scale in the microscope. The maximum linear leakage at the root-end filling material/ dentin interface was recorded for each specimen.

The results were analyzed statistically by ANOVA and Tukey's test. In all cases $p$ values $<0.05$ were considered as statistically significant.

\section{RESULTS}

The microleakage values $(\mathrm{mm})$ and standard deviation obtained by experimental groups are presented in Table 1 and Figure 1. The G1 group (COP) presented smaller dye penetration statistically different from G2 (MTA) and G3 (GIC) $(\mathrm{p}<0.05)$. No statistically significant difference in microleakage was observed between G2 and G3 groups $(\mathrm{p}>0.05)$.

\section{DISCUSSION}

The sealing ability of materials might be evaluate by dye, radioisotope, bacterial penetration, electrical impedance or resistance, hiatus measurement with scanning electron microscopy or by filtration ${ }^{10,15}$. Each technique has significant limitations that can result in errors ${ }^{8}$. The most frequently used technique is linear measurement of dye penetration ${ }^{10}$. Although this technique presents the disadvantage of semi-quantitative analyses, often involving only one plane of view ${ }^{15}$, it is the easiest method to select new materials.

COP showed excellent results in the present study when used as root-end filling material showing better results than MTA and GIC. It has been reported that this polymer is biocompatible and stimulates the bone regeneration'. The chemical composition of this material presents a chain of fatty acids whose molecular structures are also present in lipid of human body ${ }^{9}$. Therefore, the cells can not recognize the resin of COP as a strange body. According to the results presented in this study and good properties of the polymer, it can be considered a potential material for sealing of rootend cavities. Thus, the studies in this area should be wide.

The MTA group presented results inferior to COP, demonstrating high dye penetration. This result is in agreement with the study of Valois, et al. ${ }^{15}$ that evaluated in vitro the influence of the thickness of mineral trioxide aggregate (MTA) on sealing ability of root-end fillings. The thickness of $1 \mathrm{~mm}$ of MTA was the least effective to prevent apical leakage using a protein-dye complex. These authors suggest that the thickness of $4 \mathrm{~mm}$ is more adequate for using MTA as a root-end filling material. In the present study, $1.25 \mathrm{~mm}$-deep root-end cavities were prepared with size 1012 diamond burs and MTA did not promote an effective root-end sealing. However, the COP was effective to reduce 
the microleakage even in small cavities.

Several studies have demonstrated the effectiveness of MTA as root-end filling material ${ }^{5,11,14}$. However, most of these studies were performed in $3 \mathrm{~mm}$ deep cavities. In some cases, the preparation of $3 \mathrm{~mm}$ deep root-end cavities is not possible, due to difficult access. Therefore, it is important to evaluate other materials, such as COP, with capacity to promote sealing of smaller cavities since MTA is not indicated in these cases.

G3 group (GIC) presented high dye penetration in all specimens in this study. King, et al. ${ }^{6}$ reported that a glass ionomer restorative material produced significantly less sealing compared to the other materials (amalgam and SuperEBA) and cannot be recommended for use as a root-end filling material. Danin, et al. ${ }^{3}$ compared the sealing ability of amalgam, a GIC, a composite resin, and a root canal sealer as root-end filling materials using the radioactive isotopes as periapical leakage markers. These authors verified a high degree of leakage in the GIC group following in a decreasing order by amalgam, composite resin and root canal sealer (Sealapex, Kerr, MI, USA). However, Economides, et al. ${ }^{4}$ examined the sealing ability of Fuji II LC GIC with and without a new light-cured glass-ionomer bonding agent (GC Fuji bond LC) and Admira composite resin with and without the bonding agent and verified that GIC groups showed less leakage than composite-resin groups. No significant differences were found between GIC with or without bonding agent, but the values of leakage were less when a bonding agent was used. In the present study, it was used a conventional GIC (SSWhite) and no dentin acid etching was performed nor was applied a bond agent before GIC placement, according to the manufacture's instructions. During the apicetomy and root-end filling, it is recommended to use few numbers of operative steps to avoid contamination and to reduce the surgery time; Therefore, the use of GIC with dentin conditioning could delay the procedures. In a review study, Bruyne and Moor ${ }^{2}$ reported that GICs used as root-end filling materials have demonstrating contradictory results because of the methodology limitations.

The ability of root end filling materials to regenerate periapical tissues healing is as important as their sealing ability since these materials will be in contact with the periradicular tissues ${ }^{11}$. In the present study, COP presented an excellent sealing ability compared to MTA and GIC as a root-end filling material. However, further research is needed using this material in order to evaluate its physical and biological properties. COP is a relatively new and promising material in dentistry, especially as a root-end filling material.

\section{REFERENCES}

1- Ayhan H, Sultan N, Cirak M, Rubi MZ, Bodur H. Antimicobial effect of various endodontic irrigants on seleted microorganisms. Int Endod J. 1997;30:99-102.

2- Bruyne MAA, Moor RJG. The use of glass ionomer cements in both conventional and surgical endodontics. Int Endod J. 2004;37:91-104.

3- Danin J, Linder L, Sund ML, Strömberg T, Torstenson B, Zetterqvist L. Quantitative radioactive analysis of microleakage of four different retrograde fillings. Int Endod J. 1992;25:183-8.

4- Economides N, Kokorikos I, Gogos C, Kolokouris I, Staurianos C. Comparative study of sealing ability of two root-end-filling materials with and without the use of dentin-bonding agents. J Endod. 2004;30:35-7.

5- Fogel HM, Peikoff MD. Microleakage of root-end filling materials. J Endod. 2001;27:456-8.

6- King KT, Anderson RW, Pashley DH, Pantera EA Jr. Longitudinal evaluation of the seal of endodontic retrofillings. J Endod. 1990;16:30710 .

7- Mangin C, Yesilsoy C, Nissan R, Stevens R. The comparative sealing ability of hydroxyapatite cement, mineral trioxide aggregate, and super ethoxybenzoic acid as root-end filling materials. J Endod. 2003;29:261-

8- Matloff IR, Jensen JR, Singer L, Tabibi A. A comparison of methods used in root canal sealability studies. Oral Surg Oral Med Oral Pathol. 1982;53:203-8.

9- Pereira RS, Sumita TC, Furlan MR, Jorege AOC, Ueno M. Antimicrobial activity of essential oils on microrganisms isolated from urinary tract infection. Rev Saude Publica. 2004;38:1-3.

10- Roux D, Doméjean-Orliaguet S, Saade M. Leakage associated whit intermediate restorative material and glass-ionomer cement retrograde filling: a human and sheep teeth comparison with 2 different aging procedures. Oral Surg Oral Med Oral Pathol. 2002;93:81-7.

11- Tang HM, Torabinejad M, Kettering JD. Leakage evaluation of root end filling materials using endotoxin. J Endod. 2002;28:5-7.

12- Torabinejad M, Chivian N. Clinical applications of mineral trioxide aggregate. J Endod. 1999;25:197-205.

13- Torabinejad M, Pitt Ford TR, Mc Kendry DJ, Abedi HR, Miller DA, Kariyawasam SP. Histologic assessment of mineral trioxide aggregate as a root-end filling in monkeys. J Endod. 1997;23:225-8.

14- Torabinejad M, Watson TF, Pitt Ford TR. Sealing ability of a mineral trioxide aggregate when used as a root end filling material. J Endod. $1993 ; 19: 591-5$

15- Valois CRA, Costa ED Jr. Influence of the thickness of mineral trioxide aggregate on sealing ability of root-end fillings in vitro. Oral Surg Oral Med Oral Pathol Oral Radiol Endod. 2004;97:108-11.

\section{CONCLUSIONS}

The results of this study indicate that the COP presented an efficient sealing ability when used as root-end filling material showing significantly better results than MTA and GIC. 